\title{
Evaluation of the Policy Arrangement of Street Vendors in Gembong Asih Center Surabaya City
}

\author{
${ }^{1}$ Afifa Ulfa Auliya, Diana Hertati \\ ${ }^{1}$ UPN Veteran Jawa Timur, Indonesia; afifaaulia500@gmail.com \\ Received: July 5, 2021; In Revised: November 11, 2021; Accepted: December 13, 2021
}

\begin{abstract}
Policy evaluation is an essential stage for the government in implementing a policy. At this stage, it can become a bridge in entering the following policy, which is expected to be more effective in the future. This research will specifically examine Bridgman and Davis's framework to fill research gaps that have not existed before. This study aims to find out and describe the evaluation of the policy of Street Vendor Arrangement at the Gembong Asih Center, Surabaya City. The type of research used by the author in this study is descriptive qualitative with primary data and data as the data source chosen by the researcher. Then the data collection techniques used by researchers are interviews, observation, and documentation. In addition, the data analysis techniques used by researchers are data collection, data condensation, data presentation, and conclusion drawing and verification. The results of this study found that: a) The input aspect of the evaluation saw that there was suitability and availability of supporting facilities and human resources; b) The process aspect of the evaluation sees that it has been effective, efficient, and has been educated; c) The output aspect of the evaluation sees that it does not yet have an output of product success and success in influencing policy targets so that it is necessary to promote the variety of merchandise in the centre using social media, and d) The outcomes aspect of the evaluation sees that there are no overall outcomes for traders and the community. Therefore, an alternative strategy is needed to prevent traders from trading on the sidewalks by adding plants or plants or concrete balls as sidewalk safety at the curb.
\end{abstract}

Keywords: Policy Evaluation, Street Vendors, Gembong Asih Center

\section{Introduction}

The government's evaluation of a public policy is essential. This stage can be used as a stepping stone to the following policy that are expected to be more effective in the future. Policy evaluation is an effort to compare and contrast a policy's theory or regulation with its practice in the form of policy impacts, determining whether the effect is as expected or not (Anggara, 2014). When the policy evaluation procedure is implemented, the outcomes are inconsistent and reliable. As a result, it is vital to assess the policies that have been implemented by both the federal government and the local governments. Which, in this case, is in the Peraturan Walikota Surabaya Nomor 17/2003 related to Peraturan Daerah Nomor 17 Tahun 2004 about Empowering and Structuring Street Vendors. According to Arreza \& Tauran (2016), the street vendor structuring policy has not reached the established goal. This happens because the current policy's aims are not yet clear. Then, according to Dengah et al. (2017), the 
street vendor structuring policy has matched the needs. According to the study, even though the implementing officers violated the SOP, the public was not affected by the policy. Additionally, Olga et al. (2016) said that this approach is practical and well-liked by the community. While this study will look at the framework of Bridgman \& Davis thinking as described by Abdulkahar \& Teguh (2002), who suggest that measuring public policy evaluation criteria can be done using four criteria: inputs, processes, outputs, and incomes.

It is well known that Indonesia has a large population, and the country is seeing a strong movement of people from villages to cities. According to Worldometer, the number of people living in cities in Indonesia will increase during the next five years. In 2020, Indonesia's urban population was expected to reach 154.2 million people, accounting for $56.4 \%$ of the country's overall population of 273.5 million (Jayani, 2019). Naturally, as the population grows, so does the movement of people from villages to cities (urbanization), which is thought to meet their needs. However, the increase of employment opportunities in both the industrial and service sectors and the option to start a private business does not appear to balance the flow of urbanization in Indonesia. As a result, employment in the informal economy has increased. The informal sector is a viable alternative to traditional employment options that accept workers without specialized job skills or educational backgrounds. Everyday activities, according to Bromley dan Wilson (2018), are characterized by: (1) ease of entry; (2) reliance on local resources; (3) family-owned enterprises; (4) small-scale operations; (5) labour-intensive and adapted technology; (6) skills acquired outside the formal school system; and (7) unregulated and competitive markets.

Surabaya is one of the largest cities in Indonesia, and it serves as a resource for residents looking for jobs from village to town. As a result, many people have decided to become street vendors in Surabaya. Street vendors often use spaces that are not necessary as trading places, such as the roadside, sidewalks, front-of-the-store or people's homes, parks, and so on, to carry out their activities. The street vendors problem begins with an imbalance of power between two groups of people: street vendors and the government and some public interests (Tualeka, 2013). Surabaya's growing number of street vendors has resulted in many problems. Because the existence of irregular street vendors is seen as an obstacle to Surabaya City's creation of a safe, comfortable, clean, and organized layout. According to Surabaya.go.id, the population of street vendors in 2017 was 17,332 and increased significantly to 17,521 in 2018. As a result, the Keputusan Walikota Surabaya No. 17 of 2004 as an implementing rule for Peraturan Daerah Surabaya 17/2003's arrangement and empowerment of street vendors. It is stated in Article 3 that the traders' arrangement aims to achieve a harmonious environmental order, both in terms of public order, environmental cleanliness, and supporting the city's beauty.

The Surabaya City Government's next effort is to centralize the management of street vendors that are officially accommodated through the Dinas Koperasi \& UMKM into a street vendors centre. The street vendor centre has been set up with clean arrangements and tables seating to create a good space for vendors to sell their wares. The existence of a centre allows the Surabaya City Government to make arrangements so that traders do not deal in impromptu locations and are not frightened of being evicted, which is one of Gembong Asih's centres. The number of traders selling on the side of the road with makeshift pedestals has disrupted the comfort and order of city traffic. As a result, the Surabaya City Government has organized street vendors in the Gembong area by establishing Gembong Asih. The Gembong Asih Center was built to accommodate traders selling various types of used products along with the Gembong Tebasan, Kapasari, and Ngaglik areas and restore the function of the area's roads and pedestrians. 
However, even though the street vendor structuring policy in Gembong Asih Center of Surabaya has been in place for 2.5 years, there are still some problems. The first problem related to the supporting resources and basic materials needed in implementing the street vendor structuring policy, which was implemented in early November 2018, is very favourable, and traders are very enthusiastic. Still, many traders complain about a lack of buyers over time. The second problem is that, while this structuring policy has been reformed in direct services to Gembong area traders, assisted by Satuan Polisi Pamong Praja in regulating street vendors, traders continue to sell on the edge of the highway, causing traffic congestion and posing a high risk. If this is allowed, the centre that the administration established will die.

This situation is worth investigating because street vendors in the Gembong Asih Center considerably assist the government in resolving urban spatial issues. The existence of the Gembong Asih center, on the other hand, was unable to solve the problem of persistent street vendors. This study aims to find out and describe the evaluation of the policy of Structuring Street Vendors in Gembong Asih Center Surabaya City, based on the background described above. This research is designed to provide studies and sources of feedback for affiliated agencies in implementing the policy of structuring street vendors, especially in Surabaya.

\section{Methods}

The authors conducted qualitative descriptive research in this study. The research method was chosen because the researchers try to make a portrait of the evaluation of street vendor structuring policies in Surabaya's Sentra Gembong Asih. In this study, inputs, processes, outputs, and incomes were used to find the portrait using a model of public policy evaluation proposed by Bridgman and Davis.

Primary data and secondary data are the two types of data that researchers employ. For example, researchers used the following data collection techniques: a) Interviews with Dinas Koperasi \& UMKM, Linmas, Satuan Polisi Pamong Praja, and traders in Gembong Asih Center Surabaya City; b) Field observation at Gembong Asih Center in Surabaya; and c) Documentation using prepared tools such as cameras, handphones, and notebooks. What's more, data analysis techniques used by researchers include a) Data collection from informants in this study at the research site; b) Data condensation by reducing data that is not relevant to this study; c) Data presentation by displaying data that is relevant and related to research; d) As well as the withdrawal of conclusions and verification of data that has been owned at the previous stage.

\section{Results and Discussion}

Based on Peraturan Walikota Surabaya Nomor 17/200 which refers to Peraturan Daerah Nomor 17 Tahun 2004 about Empowering and Structuring Street Vendors, Article 3 says that the arrangement of street vendors is directed to realize a harmonious environmental order, both in terms of public order, environmental cleanliness, and supporting the city's beauty, in order to have a positive impact on traders and communities in Surabaya city. Given that there are numerous issues in the sector, such as the number of traders who complain about a lack of buyers even though their item does not sell, and the fact that many traders continue to sell on the side of the highway, causing traffic congestion and posing a significant risk. Suppose these 
problems and phenomena are allowed to continue. In that case, the Suraba Government-street vendor center, which centreeated to reduce congestion for effective urban governance and haveinfluenceders and the community, will fail. Based on the above problems, an assessment of the policies that have been implemented is required to determine the policy's scope and determine which sectors or elements of the policy need improvement.

In previous research, Arreza \& Tauran (2016) found that the policy of structuring street vendors has not reached the target that has been set. This happens because the current policy's aims are not yet clear. Then, according to Dengah et al. (2017) said the policy of structuring street vendors has matched the needs. According to the study although the implementing officers violated the SOP, the public was not impacted by the policy. Furthermore, Olga et al. (2016) said that this policy is effective and well-liked by the community. At the same time, the study will focus on Bridgman and Davis's mindset in order to fill in research gaps that have previously existed. Whereas Brigman and Davis, as quoted by Abdulkahar \& Teguh (2002), argue that four criteria can be used to characterize public policy evaluation criteria: input, process, outputs, and outcomes.

\section{Inputs}

The first area of focus is input, with indicators such as supporting resources/facilities and human resources, according to Krisnina (2017). Water, electricity for lighting each block, stands for traders, large parking lots, mushola, toilet, and carts for food and beverage sellers are among the infrastructure facilities given by the Dinas Koperasi \& UMKM in The Gembong Asih Center, according to the findings of the research. The facilities and infrastructure in Gembong Asih Center Surabaya City are in good condition and suit the needs of traders. It may be concluded that the Surabaya City Dinas Koperasi dan UMKM has provided adequate support for the implementation of street vendor structure policies in Gembong Asih Center Surabaya City. This is in line with Damanik dan Marom (2016), who stated that supporting resources are essential when developing policy. This is in accordance with the street vendor arrangement at the Gembong Asih Center in Surabaya City, where there are investing resources, in this instance, infrastructure facilities given by the Surabaya City Government in order to implement the policy of structuring street vendors.

Then, to carry out the policy of Structuring Street Vendors in Gembong Asih Center, Surabaya City required sufficient human resources in terms of quantity and capability. Several officers who are managers of The Gembong Asih Center and supervisors, namely field coordinators from the Dinas Koperasi \& UMKM and Linmas as security and market supervisors, are involved in the process of structuring street vendors in Gembong Asih Center. Compared to the number of officers who plunged to the ground, the number is still deficient. However, the Dinas Koperasi \& UMKM lines officer and field coordinator attempted to maximize the number of workers covering the Gembong Asih Center region. Furthermore, the officers come from agencies in their domains and in accordance with their primary duties when viewed from the ability or background of street vendors. So that the officers have the necessary skills, this is in line with Akibu (2014) statement that sufficient human resources and capabilities play a critical role in policy implementation. This emphasizes the importance of human resources in ensuring that a policy is implemented in accordance with expectations.

\section{Process}

In the Gembong Area, the process refers to how a policy is transformed into direct service to street vendors. According to Lintjewas et al. (2016), there are indications throughout the process, such as efficacy, efficiency, and education studies. To determine how the success 
of the street vendor structuring policy in Gembong Asih Center Surabaya city can be determined by deciding targets and location. Based on the research findings, it was discovered that the target was determined using the Regional Regulation of Surabaya City Number. 17 the Year 2003, with the intended target being traders with Surabaya ID cards who meet the specified conditions to occupy a stand-in Gembong Asih Center according to the regulations. The following are the conditions for registering as a street vendor: 1) A Surabaya ID is required. 2) Obtaining a letter of recommendation from a Camat whose work area includes the sought street vendor location; 3) photographing accessories to be utilized in the stand, and 4) completing affidavits. The Dinas Koperasi and UMKM Surabaya City will verify that all prerequisites have been met. Furthermore, establishing the position of street vendors based on a strategic location with high accessibility and supported by traffic conditions that are consistent with the Gembong Asih street vendors' business activities. In order to support trading activity, this location must have complete and suitable amenities. It must also have some infrastructure to support the location's existence and be positioned near the citizens' settlement. Easy access and a strategic location adjacent to inhabitants' settlements were essential factors in the decision.

The regulators of Bappeko Surabaya, Dinas Koperasi Surabaya, Disperindag Surabaya, and PD Pasar Surya assist in determining the location by taking into account various factors such as accessibility and road patterns in Gembong Asih in supporting trade activities, areas not far from where street vendors usually sell, easily accessible locations and public transportation around the site are also easily found by the public. As a result, it can be inferred that the government has considered both the positives and negatives of the Centre's future location in determining the location. This is in line with Maijun \& Utama (2013) belief that the policy will be effective if the target selection procedure is based on existing regulations and the location selection is based on ease of access.

Furthermore, to determine how the efficiency of the street vendor structuring policy in Surabaya's Gembong Asih Street Vendors Center may be improved by relocation and repression. According to the result of the research, the process of relocating street vendors to the Gembong Asih Center began with the coordination of the Dinas Koperasi \& UMKM, Subdistrict, Village, Satuan Polisi Pamong Praja, Dinas PU (Binamarga) related to culverts and development, as well as the Surabaya Police and Army. Additionally, coordination and communication with necessary parties are required in order for traders to wish to relocate. The next step is for Satpol PP to tag the area by placing a banner in a strategic location to alert the public that traders have been relocated to The Gembong Asih Center. The placement of this banner serves as a reminder that street vendors selling on the sidewalk have been relocated to Surabaya's Gembong Asih Center.

Then, in the repressive process of officers against traders, disciplining traders who violate to promote harmonious conditions between officers and vendors, particularly at The Gembong Asih Center. Lines and the Dinas Koperasi \& UMKM always socialize about local restrictions on street vendors and communicate directly with vendors to build a harmonic climate between traders and police to realize harmonious conditions amongst Gembong Asih traders. Lines also advises traders always to follow the rules that have been agreed upon by both parties. Furthermore, as part of the government, Satpol PP consistently assists traders who have broken the rules. But, if vendors do not follow the established regulations, Satpol PP will not hesitate to take action. Officers at Surabaya's Sentra Gembong Asih Surabaya's street vendor arrangement take decisive action against traders who break the rules. A warning letter to the relevant traders is one such step. Repressive officers have done it in the arrangement of traders in Gembong Asih Center Surabaya city. 
In terms of education, the research found that at the Gembong Asih Center, the informal sector's education bucket, which includes street vendors, includes providing coaching so that they can understand the rules and laws imposed by the government, as well as the steps that need to be taken to improve their business. Of course, assimilation to policy aims about policies established later is required in the layout of street vendors in Gembong Asih Center Surabaya. This socialisation aims for traders to comprehend the contents of Peraturan Daerah No. 17/2003 on Street Vendor Structuring and Empowerment. Additionally, as the manager and accountable for Gembong Asih Center, Dinas Koperasi \& UMKM always provide education to traders in order to progress the economy and welfare of traders. Dinas Koperasi \& UMKM offered street vendors at Gembong Asih Center education or understanding in counselling and socialization. Coaching is provided to all street vendors through activities such as counselling on the cleanliness of the environment in which the trader sells and how to maintain city order in this case through the use of public space, such as not disturbing or using a place intended for pedestrians, as well as providing coaching to traders to conduct trading activities outside of the market. But also sell merchandise through social media such as advertising, Instagram, Facebook, or other marketplaces. With this education, traders' economies can be aided, rather than relying on purchasers who purchase goods straight from the market. This demonstrates that the government has done an excellent job educating street vendors about the process.

The above explanation of relocation, repressive, and education shows that the efficiency of the street vendor arrangement in Gembong Asih Center Surabaya city is consistent with Rusydiana (2018:49) theory that the relocation process is efficient, repressive steps from officers, and education.

\section{Outputs}

The evaluation of the public policy process outcomes is referred to as output. Outputs include assessments of the items created as well as success in influencing policy goals, according to (Taufiq \& Junadi, 2019). According to the study's findings, the products produced were found to be related to the results of the Keputusan Walikota Surabaya 17/2004 in addressing the problem of structuring street vendors in Gembong Asih Center. Whether or not the policy outcomes met their requirements and provided them with options. This raised more questions about the role of policy outcomes in addressing policy issues and the extent to which gaining results can alleviate problems. The Keputusan Walikota Surabaya 17/2004 results in overcoming the problem of street vendor structuring at Gembong Asih Center can be deemed to have failed to overcome the existing problems. When seen through the lens of urban planning, it is clear that this policy has the potential to alleviate present traffic congestion. However, in terms of meeting the needs of existing policies, traders have fallen short of the expectations of street vendors, who are the policy's intended aim. Many traders at the Gembong Asih Center have noticed a significant drop in their turnover and income and have decided not to sell. This shows that the resulting product sub focus did not meet the policy objectives' demands and expectations. This contradicts Duri \& Rahmah (2020:50) assertion that the final policy can resolve existing issues.

In terms of success in influencing policy goals, the study found as many as 380 active traders who perform trading activities in The Gembong Asih Center successfully follow the policy of structuring street traders as the target of this policy. Additionally, most merchants sell tertiary products such as used clothes, glasses, watches, belts, and so on. It is known that the government has granted a total of 404 stands. Dealers occupied the whole stand during the first stage of the building, but as many as 24 frames are still empty and not occupied by traders during the second stage of development. This shows that there are still some unoccupied 
booths, namely 24 . When contrasted to the current reality, there are still roadside vendors. As a result, the number of traders who successfully follow the policy of structuring Street Vendors in The Center of Gembong Asih Surabaya City based on Keputusan Walikota No. 17/2004 can be stated have failed in impacting policy goals in this case. This contradicts Nugroho (2018:786) assertion that a policy is successful if it can persuade the target to follow it. This is shown by the growing number of traders returning to sell outside the Center, demonstrating that some merchants are overlooking the regulations that have been established. According to the government, inviting traders to Sentra was also challenging because some merchants rented land from the locals.

\section{Outcomes}

Outcomes refer to the policy's impact on the general public or those who are affected by it. What is meant is the relationship between the effect on street vendors as a policy objective and the impact on the community. According to the findings of the research, the influence experienced by street vendors is known to be related to place and income. In terms of the location, traders are more relaxed and at ease, because they have a site with selling permission, and they don't have to worry about being arrested by Satpol PP police in Surabaya. However, when looking at the income earned by traders, there was a considerable decrease. Even the payment of dealers is negligible under the current epidemic conditions. This demonstrates that policy aims have not had the full positive impact predicted. This is in contrast to (Lafitra Marsha Krisnina, 2017), who believes that the effect received policy targets must be in line with expectations.

In terms of the community's reaction, the study's findings revealed that many people believe the Surabaya City Government succeeded in relocating street vendors by implementing a solution in the shape of Sentra Gembong Asih. The state of the highway is immaculate and beautiful due to this program. No traffic congestion is caused by street vendors or buyers, who frequently obstruct traffic flow. Quite different from before the dealers' arrangement. Previously, every corner of the Gembong Area was constantly clogged with street vendors and buyers, suffocating the streets. As a result, it can be concluded that the impact of the street vendor arrangement in Sentra Gembong Asih on the larger community is more towards smooth traffic, less congestion, and a cleaner, more organized, and more comfortable to observe highway. In Sentra Gembong Asih Surabaya City, there is a substantial difference between before and after the street vendor layout. This shows that society's impact on the focus of outcomes is already well-received and meaningful by society as a whole. This is in line with Lejiu (2014), which states that the community's impact on the government's policies must be as expected by the community. Then and only then can this policy be considered a success.

\section{Conclusion}

Based on the results of research and discussion related to the Evaluation of Street Vendor Structuring Policy in Gembong Asih Center City, the author can draw the following conclusions:

1. The input aspect of the evaluation sees that there is already conformity and availability of supporting facilities and human resources. However, it is necessary to maintain the condition of existing infrastructure facilities so that the facilities received by traders are still in a state of service for a more extended period of time. 
2. The process aspect of the evaluation sees that it is effective, efficient, and has educated. But the issue of education needs to be improved in consistency so that traders who are already in the Center will not trade in areas prohibited by the government.

3. The output aspect of the evaluation sees that it does not yet have the resulting product success output and success in influencing policy objectives. Therefore, it is necessary to promote the variety of merchandise in the Center using social media because not many of them respond to digital-related information. Thus, the Dinas Koperasi \& UMKM of Surabaya City need to increase this promotion that the economy of Gembong Asih Center traders can grow again.

4. The outcomes aspect of the evaluation sees that it does not yet have overall outcomes in traders and the public. Therefore, alternative strategies are needed to prevent traders from trading on sidewalks by adding plants or plants or concrete balls as sidewalk safety on sidewalks. In addition, the road's shoulder can minimize street vendors selling on the sidewalk. As well as to protect pedestrians from motor vehicles and to beautify or add to the aesthetics of Surabaya City.

\section{References}

Abdulkahar, B., \& Teguh, Y. (2002). Kebijakan Publik Konsep dan Strategi. Undip Press.

Ahmad Sururi. (2019). Kinerja Implementasi Kebijakan Penataan dan Pemberdayaan Pedagang Kaki Lima dan Strategi Inovasinya di Kawasan Pasar Royal Kota Serang. Wacana Kinerja, 22(2).

Anggara, Sahya. (2014). Kebijakan Publik. CV Pustaka Setia.

Areeza, \& Tauran. (2006). Evaluasi Kebjakan Penataan PKL di Sentra PKL Manukan Lor Kota Surabaya. Jurnal Kajian Publik 1(1).

Bromley, R., \& Wilson, T. D. (2018). Introduction: The Urban Informal Economy Revisited. Latin American Perspectives, 45(1).

Dengah. Junior, \& Novie Pioh., Josef Kairupan. (2017). Evaluasi Kebijakan Penertiban Pedagang Kaki Lima di Kota Manado. Jurnal Jurusan Ilmu Pemerintahan 2(2).

Duri, R., \& Rahmah, M. (2020). Evaluasi Pemekaran Daerah Dalam Peningkatan Kesejahteraan Masyarakat. Jurnal Kebijakan Pemerintahan, 3(1), 43-52.

Fajrin, R. M., \& Rahmawati, D. (2016). Faktor-Faktor yang Berpengaruh dalam Penataan Pedagang Kaki Lima (PKL) pada Koridor Jalan Pasar Besar Kota Malang. Jurnal Teknik ITS, 5(1), 146.

Harahap, F. R. (2013). Dampak Urbanisasi Bagi Perkembangan Kota Di Indonesia. Society, 1(1), 35-45. https://doi.org/10.33019/society.v1i1.40

Jayani, D. H. (2019a). Berapa Jumlah Penduduk Perkotaan di Indonesia? Databoks.

Jayani, D. H. (2019b). Sektor Informal Mendominasi Pekerjaan di Indonesia 2015-2019. Databoks.

Lafitra Marsha Krisnina. (2017). Studi Evaluasi Kebijakan Retribusi Parkir Berlangganan di Kabupaten Sidoarjo. Kebijakan Dan Manajemen Publik, 5(3).

Lejiu, A., Masjaya, \& Irawan, B. (2014). Evaluasi Kebijakan Pembangunan Transmigrasi di Kabupaten Mahakam Ulu (Studi Pada Kecamatan Long Hubung Kabupaten Mahakam 
Ulu). Jurnal Administrative Reformeform, 2(4), 515-526.

Lintjewas, O. Y. L., Tulusan, F., \& Egeten, M. (2016). Evaluasi Kebijakan Pemberian Bantuan Pengembangan Usaha Mina Perdesaan di Kabupaten Minahasa Selatan. Ilmu Sosial Dan Pengelolaan Sumberdaya Pembangunan, 20(2).

Maijun, \& Utama, S. J. (2013). Efektivitas Pelaksanaan Program Urban Farming di Kelurahan Medokan Ayu Kecamatan Rungkut Kota Surabaya (pp. 1-12).

Nugroho, R. (2018). Public Policy (Y. Masda (ed.); 6th ed.). PT Elex Media Komputindo. https://doi.org/718061277

Olga., Lintjewas, Tulusan, \& Maxi Egeten. (2016). Evaluasi Kebijakan Pemberian Bantuan Pengembangan Usaha Mina Perdesaan di Kabupaten Minahasa Selatan. Jurnal Ilmu Sosial dan Pengelolaa Sumberdaya Pembangunan 2(2).

Peraturan Walikota Surabaya Nomor 17 Tahun 2004 Tentang Pelaksanaa Peraturan Daerah Nomor 17 Tahun 2004 Tentang Pemberdayaan dan Penataan Pedagang Kaki Lima

Rusydiana, A. S. (2018). Indeks Malmquist untuk Pengukuran Efisiensi dan Produktivitas Bank Syariah di Indonesia. Jurnal Ekonomi Pembangunan, 26(1), 47-58.

Taufiq, A., \& Junadi. (2019). Evaluasi Kebijakan Pengisian Perangkat Desa Secara Serentak di Kabupaten Bojonegoro. Ilmiah Manajemen Publik Dan Kebijakan Sosial, 3(2).

Tualeka, B. A. (2013). Memahami Kebijakan Pembinaan Pedagang Kaki Lima Surabaya. Administrasi Publik, 11(1), 146-158.

Winarno, B. (2014). Kebijakan (Publik Teori, Proses, dan Studi Kasus). CAPS: (Cnter of Academic Publishing Service). 